$\xi^{2}=$

\title{
Assessment of Polycyclic Aromatic Hydrocarbon in Soils and Sediments in Onitsha area, Southeastern, Nigeria
}

\author{
Asowata Iyobosa.Timothy ${ }^{1}$, Olatunji Akinade Shadrach ${ }^{2}$ \\ ${ }^{1}$ Department of Applied Geology, Federal University of Technology, Akure, Nigeria \\ ${ }^{2}$ Department of Geology University of Ibadan, Ibadan, Nigeria \\ *Corresponding author E-mail: itasowata@futa.edu.ng
}

\begin{abstract}
Polycyclic Aromatic Hydrocarbons (PAHs) are environmental pollutant that can impair environmental quality and health, and consequent ecological risk. The study was aimed at determining the concentration and environmental status of PAHs in the soils and sediments of Onitsha metropolis and identify their probable source(s). Sixty samples of soils (44) and sediments (16) were collected for the study. Extraction of organics was facilitated by infusing the samples with dichloromethane and subjected to ultrasonic agitation. The analyses of the PAHs were undertaken using gas chromatography/mass spectrometry (GC/MS).

Thirteen PAHs were detected in soils and sediments exhibiting varying concentration across several sampling locations. The concentration range $(\mu \mathrm{g} / \mathrm{kg})$ of the 13 identified PAHs in soil and sediments were Fluorene 0.00 - 122.2and 1.7-31.1; Anthracene, 0.0 - 55.3and 1.7 - 46.0; Phenathrene 1.0 - 2045.8and 22.2 - 266.2; Fluoranthene, 1.0 - 483.7and 13.4 - 602.9; Pyrene, 3.7 - 533.4and 14.1 - 531.8; Benzo [k]fluoranthene 1.0 - 166.5; 4.0 - 163.5; Benzo[a]anthracene, 1.0 - 222.0; 5.6 - 298; Benzo[b]fluoranthene, $1.1-502.6$ and 14.1 - 452.9; Dibenz[ah]anthracene 1.0 - 33.4 and 1.037 0; Chrysene, 1.0 - 426.4and 10.0 - 385.6; Benzo [a] pyrene 1.0 - 502.6and 12.9 514.9 Benzo[ghi]perylene, 1.0 - 557.8and 14.9 - 326.0; Indeno[123-cd]pyrene 1.0 - 412.2and 1.0 - 37.0, respectively The fractional concentration of PAHs and Total Organic Carbon (TOC) analysed using Principal Component Analyses revealed different partitioning of the TOC and PAHs in soils and sediments. This indicated distinct sourcing of the TOC and PAHs in the environmental media. Relatively higher concentrations of PAHs were found in environment characterized by combustion activities such as waste dump sites, Mechanic and Metal Works environments. Pyrogenic (combustion) activities were indicted as the main contributors of the PAHs to the soils and sediments.
\end{abstract}

Keywords: Carcinogenic; Soils; PAH Pollutant; Health Risk; Environment.

\section{Introduction}

Polycyclic aromatic hydrocarbons (PAHs) are group of organic compounds consisting of two or more fused aromatic rings. They occur in the environment either through petrogenic processes such as volcanic eruptions or pyrogenic sources, particularly from incomplete combustion of organic compounds. These sources can occur naturally or could be human induced (Chung et al., 2007). Vila-Escale et al., 2007, have identified the main natural sources of PAHs to include forest fires and volcanic activities respectively. While the major anthropogenic sources include the burning of fossil fuels, petroleum spills, and industrial discharges (Hafner et al., 2005; Johnsen et al., 2006, Chung et al., 2007). Base on this, PAHs are widespread in ambient environment as well as in identified contaminated hotspots (Simpson et al., 1996; Johnsen et al., 2006).

16 PAH have been classified to be generally harmful to human health especially when its bio availability exceed acceptable concentration limit, these include; Naphthalene, Acenaphthylene, Acenaphthene, Fluorene, Anthracene, and Phenanthrene. Others are; Fluoranthene, Pyrene, Benzo[a]anthracene, Chrysene, Benzo[k]fluoranthene, Benzo[a]pyrene, Benzo[b]fluoranthene, Benzo[ghi]perylene, Indeno(1,2,3-cd)pyrene and Dibenz[ah]anthracene. Different PAH compounds have different toxicity levels. Of the 16 Environmental Protection Agency (EPA) priorities PAH compounds, seven (7) are designated as probable human carcinogens with varying potency levels (Baumard, 1999), United State Environmental Agency (USEPA, 2002). The ratios of particular PAH compounds or isomers, such as phenanthrene/anthracene and fluoranthene/pyrene, have been used as source indicators for PAH contaminated environments (Yunker et al., 2002; Pies et al., 2008; Liu et al., 2008 and Zhen et al., 2011).

The activities in large (urban) cities and towns affect greatly the quality of the environment by contributing to increasing concentration of polycyclic aromatic hydrocarbon (PAHs) in soils, water (surface and groundwater), sediments and particulate,(Appleton and McCall, 1996, Torben et al., 1996; Trapido, 1999; Wendi, et al 2011). Onitsha, which was the study area, is a densely populated city with continuous expansion due to rapid urban migration and with variable land use, as seen in figures 1,2 and 3 . The possible enrichment of organic pollutants such as PAHs in soils and sediments in the environment is in no doubt a matter for concern, hence this study. Information on the spatial distribution of PAHs in soils and sediments are obviously not available, which makes this study of great relevance. The aim of this study was to determine the spatial distribution of PAHs and identify the source(s) of these organic pollutant in soils and sediments in the study area. 
The climate is tropical equatorial, with well defined wet and dry seasons. The wet season runs from March through October with a lull in August usually called August break. This nearly divides the wet season into two. The remaining months constitutes the dry season period. Like a good portion of West Africa, the city experiences the harmattan (dry) season between the months of November and February. The study area is drained by River Niger that runs from North to South of the city, and its tributaries, Nkisi and NdeMilli Rivers. The NdeMilli river drian the southern part of the city from East to west, while the Nkisi river also drain the city from East to West in the Northern part, figure 4 . These three rivers play critical role in irrigation of farming during the dry by the flood plains, dredging of sand, fishing among others.

The Onitsha area is underlain by the Ameki Formation and it is bounded at the western part of the area is bounded by the river Niger with edge of the River housing the alluvial deposits (Figure 5). The Ameki Formation is Eocene in age and its lateral facies equivalence is the Nanka Formation. The Ameki Formation consists of a series of highly fossiliferous grayish-green sandy clay with calcareous concretions and white clayey sandstone. It comprises two lithological groups. The lower groups is composed of fine to coarse grained sandstone with intercalation of calcareous shale and thin shaly limestone while the upper part consists of coarse grained cross bedded sandstone with bands of fine grey-green sands and sandy clay (Reyment, 1965). Nwajide (2013) refers to the Ameki Formation to have between 1200ft to $1500 \mathrm{ft}$ with regressive facies, shallow marine environment as assigned. The formation overlies the Imo Formation. Its lateral equivalente is the Nanka sand.

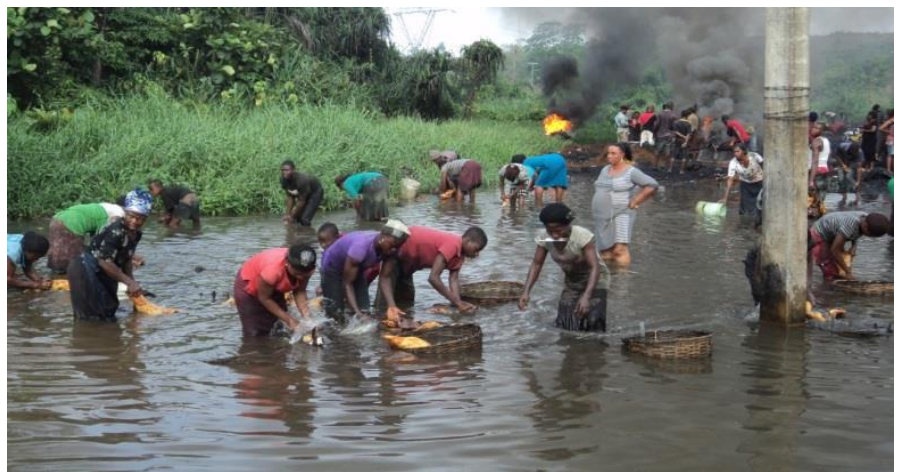

Fig. 1: Photograph of Some Inhabitants Washing Meat in the Waste Laden River E 6 $50^{\prime} 52.832^{\prime \prime} \mathrm{N} 6^{\circ} 3^{\prime} 37.49^{\prime \prime}$.

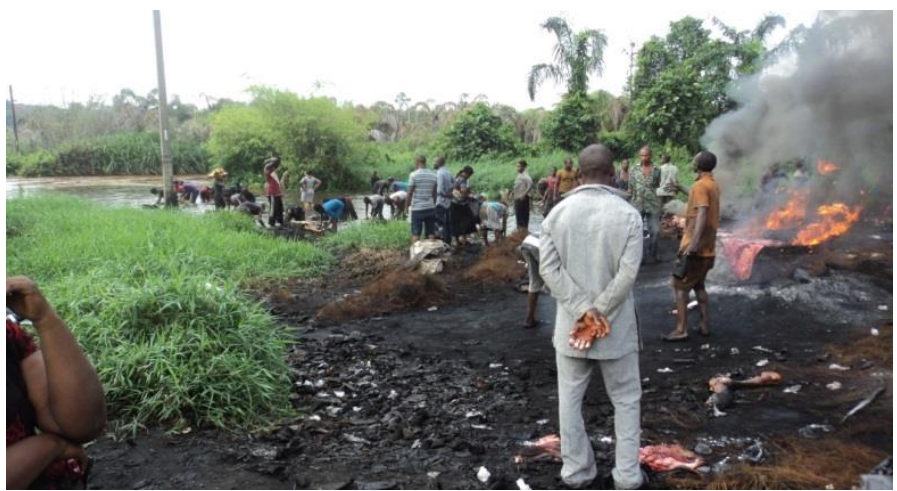

Fig. 2: Photograph of an Abattoir Where Meat Is Being Processed with Bunt Tyre Very Close to Ndemilli River E 6 $6^{\circ} 50^{\prime} 52.732^{\prime \prime} \mathrm{N} 6^{\circ} 3^{\prime} 37.96^{\prime \prime}$.

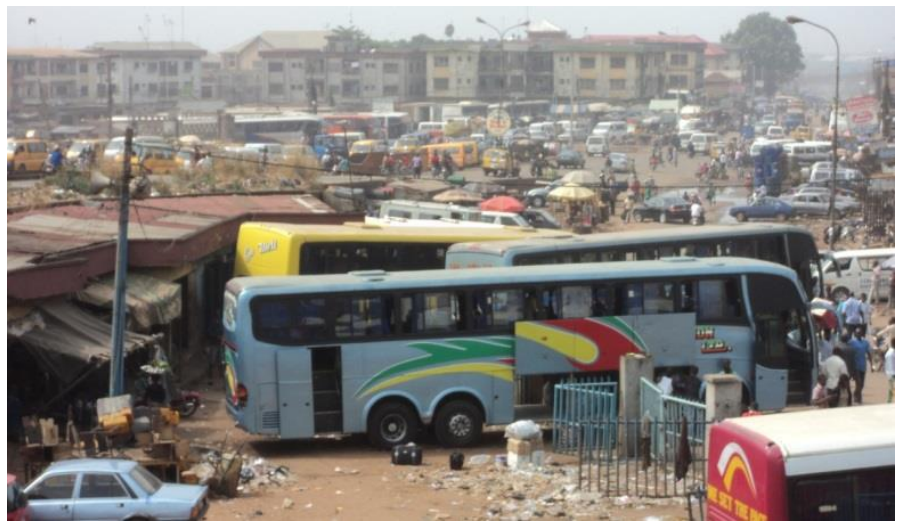

Fig. 3: Photograph Showing Over Crowded Bus Park at Upper Iweka (E6 ${ }^{\circ} 47^{\prime} 50.928^{\prime \prime}$ N6 $6^{\circ}$ ' 24.376". 


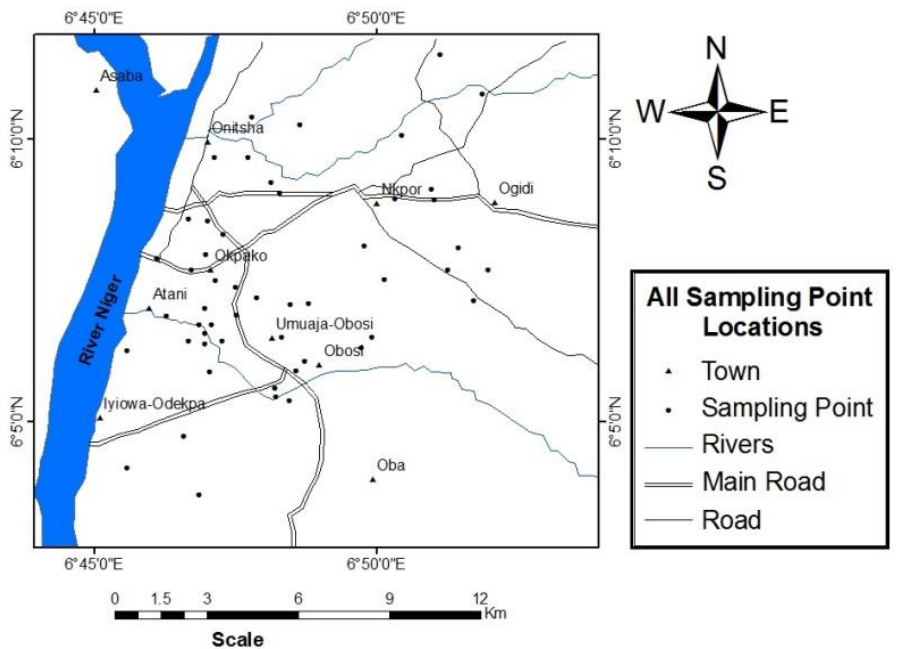

Fig. 4: Location Map of the Study Area (Modified Sheet 263, Federal Survey Nigeria, 1964).

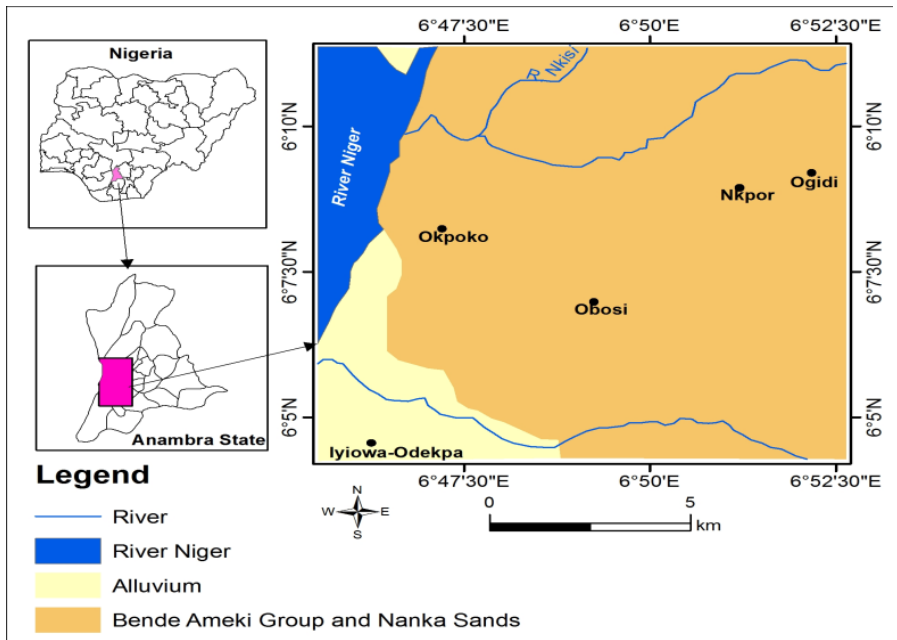

Fig. 5: Geologic Map of Onitsha Area, Part of Sheet 71 (Modified After Geological Survey of Nigeria, 1957).

\section{Material and methods}

\subsection{Sample collections}

Soil and Sediment samples were collected from different location in the study area, figure 4. For the soil samples $(\mathrm{N}=44)$, sampling were carried out in selected areas, putting into consideration densely populated area, industrial areas, places close to waste dump sites and outskirt (control) of the city. While for the sediments samples, a total of 16 samples were collected mainly from high traffic roadside sediments, NdeMilli and Nkisi Rivers respectively, which drain more than $90 \%$ of the study area. For the soil samples, in some locations, samples were taken both at top soil $(0-30 \mathrm{~cm})$ depth and subsoil $(>30 \mathrm{~cm}-1 \mathrm{~m})$ depth. In each of the chosen location, three sub samples were collected at a distance of an average of forty (40) meters away before harmonising to form a single sample. Also for the sediments three sub samples were collected within a distance of ten meters apart before harmonising the samples as one representative sample. The soil samples were collected using sample auger that is about $1.5 \mathrm{~m}$ in length. All samples were kept at relatively low temperature of $<6{ }^{0} \mathrm{C}$ and at dark room for further geochemical analyses. The sampling followed different land use, these include Residential Area (RA), Farmland and Garden (FLG), Active waste dump (AWD), Mechanic and metal workshops (MMW), Market and Abattoirs (MAP), Schools and Office complexes (SOC) and Control samples (CT) from relatively pristine areas. While for the sediment samples, they include Roadside Drain sediment (RSD), Ndemilli River (ID) and Nkisi River (NK).

\subsection{Total organic carbon determination}

Parts of the samples were grounded to $200 \mu \mathrm{m}$ and analysed on a LECO CS 230 carbon-sulphur-analyser for Total Organic Carbon content (TOC). The TOC was determined after removing carbonates with $2 \mathrm{~N} \mathrm{HCl}$ at $80{ }^{\circ} \mathrm{C}$.

Soluble organic matter was extracted from the pulverized sample using a Dionex ASE 350 apparatus. The extraction was performed at 80 ${ }^{\circ} \mathrm{C}$ and 1500 psi pressure in three cycles using dichloromethane as the solvent. All the processes were carried out following instrument instruction guidelines.

\subsection{Determination of PAHs}

Polycyclic aromatic hydrocarbon in 60 soil and sediment samples were analysed by gas chromatography/mass spectrometry (GC/MS), using a HP-7890 instrument equipped with a PTV inlet splitting on two DB-1 columns. (each $50 \mathrm{~m} ; 0.2 \mathrm{~mm}$ i.d.; film thickness $0.11 \mu \mathrm{m}$ ), one coupled to a flame ionisation detector (FID) the other one to an Agilent 7000 QQQ mass spectrometer. Helium was used as carrier gas $(27 \mathrm{~cm} / \mathrm{s})$. The columns were heated from $50{ }^{\circ} \mathrm{C}$ to $200{ }^{\circ} \mathrm{C}$, at a rate of $20^{\circ} \mathrm{C} / \mathrm{min}$, then heated to $300{ }^{\circ} \mathrm{C}$, at a rate of $10{ }^{\circ} \mathrm{C} / \mathrm{min}$, this 
temperature was held for additional 15 min. Compounds were identified by comparison of mass spectra and retention times with commercial standards. Quantification of 16 PAHs was done via MRM-measurements.

\section{Results and discussions}

\subsection{Geochemistry of polycyclic aromatic hydrocarbon (PAHs) in soils and sediments}

The summary results of the concentrations of polycyclic aromatic hydrocarbon for soils and sediments in the study area are presented in Table 1 and 2. Of the 16 PAHs, analysed for, 13 PAHs were detected in the soils and sediments with varying concentration from one location to the other. These PAHs include Fluorene, Anthracene, Phenanthrene, Fluoranthrene, Pyrene, Benzo[a]anthracene, Crysene, Benzo[b]fluoranthene, Benzo[ghi]perylene, Indeno(1,2,3-cd)pyrene and Dibenzo[ah]anthracene. The other three PAHs that were not detected include Naphthalene, Acenaphthylene and Acenaphthene. The result of the concentration of Fluorene was found to be relatively high in soils collected from Mechanic and metal workshop vicinity with the highest concentration of Fluorene found in location MMW/11 $(122.2 \mu \mathrm{g} / \mathrm{kg})$. Other locations with relatively high concentration of Fluorene in $(\mu \mathrm{g} / \mathrm{kg})$ include MMW/9 (33.7), MWM/2A (16.9), ID/3 (20.1), ID/4 (31.1), ID/6 (20.2), ID/9 (12.9), AWD/3A (36.7) and MAP/2 (15.3). Most of the samples in FLG, SOC and the control samples were found to be below detection limit. Summary result for Fluorene is contained in Table 1 and 2.

The content of Anthracene concentration showed varying concentration from one location to the other. The highest concentration was

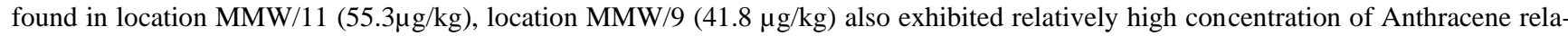
tive to most other locations were low concentration were found. Examples of such were locations FLG 3A, RA 20, SOC 5 among others with concentration (1, n.d and 1) in $\mu \mathrm{g} / \mathrm{kg}$ respectively. Both the Roadside drain sediments and the sediments from river Nkisi and NdeMilli exhibited relatively high concentration $(\mu \mathrm{g} / \mathrm{kg}$ ) of Anthracene; ID/1 (27.9), ID/2 (37.1), ID/3 (23.5), ID/4 (30.0), ID/5 (46.0), NK/1 (14.3) and NK/2 (16.2).

The concentration of Phenanthrene also exhibited varying distribution in concentration in both the soils and sediment. The highest concentration of Phenanthrene was found in location MMW/11 $(2045.8 \mu \mathrm{g} / \mathrm{kg})$. Other locations with relatively high concentration of Phenenthrene were AWD/5A $(245.3 \mu \mathrm{g} / \mathrm{kg})$, MAP2 $(229.9 \mu \mathrm{g} / \mathrm{kg}), \mathrm{RSD} / 20(227.9 \mu \mathrm{g} / \mathrm{kg}), \mathrm{ID} / 3(208.6 \mu \mathrm{g} / \mathrm{kg}), \mathrm{ID} / 4(266.2 \mu \mathrm{g} / \mathrm{kg})$ among others. Comparing these results with the control sample CT/4 $(1.0 \mu \mathrm{g} / \mathrm{kg})$ as well as other locations with relatively low concentration, it can be said there is considerable enrichment of Phenanthrene in those to over 2 to 10 fold.

Fluorathene concentration in soils sediments in the study area also exhibited spatial distribution as seen in the other compound earlier discussed. Relatively higher concentration of Fluorathene were found in locations RSD $/ 20(602.9 \mu \mathrm{g} / \mathrm{kg}), \mathrm{MMW} / 11(463.5 \mu \mathrm{g} / \mathrm{kg})$, AWD $/ 5 \mathrm{~A}(483.7 \mu \mathrm{g} / \mathrm{kg})$, compare to other locations with relatively low concentration, such locations include CT/4 (1.0 $\mu \mathrm{g} / \mathrm{kg}), \mathrm{SOC} / 2 \mathrm{~A}$ $(9.2 \mu \mathrm{g} / \mathrm{kg})$, and FLG/3A $(4.1 \mu \mathrm{g} / \mathrm{kg})$ among others.

The concentration of Pyrene in the study area was found to vary from one location to the other. Relatively high concentration were found in locations MMW/3A (431.5 $\mu \mathrm{g} / \mathrm{kg})$, MMW/11 (533.4 $\mu \mathrm{g} / \mathrm{kg}), \mathrm{ID} / 9(531.8 \mu \mathrm{g} / \mathrm{kg})$, compare to the control samples CT/4, and CT/1 which recorded NOT Detected (n.d) and some other locations with relatively lower concentration; FLG/3 (3.7 $\mu \mathrm{g} / \mathrm{kg}), \mathrm{SOC} / 2 \mathrm{~A}(7.1$ $\mu \mathrm{g} / \mathrm{kg}$ ) among others. Other locations exhibited moderate to low concentration,

Benzo (a) anthracene compound concentration in the study area exhibited spatial variation in concentration in soils and sediments of the study area. Relatively high concentration were found in locations MMW/11 (127.8 $\mu \mathrm{g} / \mathrm{kg}), \mathrm{RSD} / 20(298.3 \mu \mathrm{g} / \mathrm{kg}), \mathrm{ID} / 9(226.6 \mu \mathrm{g} / \mathrm{kg})$ when compared with the control samples; CT/4 (n.d) and CT/2 $(1.0 \mu \mathrm{g} / \mathrm{kg})$. Other locations exhibited moderate to low concentration of Benzo (a) anthracene.

Chrysene compound in the study area was observed to be present in the soils and sediments in varying concentration from one location to the other. Relatively high concentration were observed in location MMW/10 (426.4 $\mu \mathrm{g} / \mathrm{kg}), \mathrm{MMW} / 11(348.5 \mu \mathrm{g} / \mathrm{kg}), \mathrm{RSD} / 20(336.8$ $\mu \mathrm{g} / \mathrm{kg})$, MAP $/ 2(204.1 \mu \mathrm{g} / \mathrm{kg})$ among others, compare to the concentration of the control samples; CT/4 (1.0 $\mu \mathrm{g} / \mathrm{kg})$, and CT/2 (3.9 $\mu \mathrm{g} / \mathrm{kg})$. Other locations with relatively low concentration of Chrysene include FLG/3A $(1.3 \mu \mathrm{g} / \mathrm{kg}), \mathrm{RA} / 21(8.1 \mu \mathrm{g} / \mathrm{kg})$ among other locations.

Benzo[k] Fluoranthene compound exhibited varying concentrations in the soils and sediment that were analysed. Relatively moderate to low concentration were observed in virtually all the locations. Areas with relatively high concentration, include MMW/9 (166.5 $\mu \mathrm{g} / \mathrm{kg})$, $\mathrm{SSD} / 20(163.5 \mu \mathrm{g} / \mathrm{kg}), \mathrm{ID} / 9(106.6 \mu \mathrm{g} / \mathrm{kg})$, and MAP/2 $(84.9 \mu \mathrm{g} / \mathrm{kg})$ compare to the result from the central samples, such as CT/4 (n.d), $\mathrm{CT} / 2(1.0 \mu \mathrm{g} / \mathrm{kg})$ as well as other locations with relatively very low concentration; FLG/3A $(1.0 \mu \mathrm{g} / \mathrm{kg}), \mathrm{SOC} / 2 \mathrm{~A}(2.4 \mu \mathrm{g} / \mathrm{kg}), \mathrm{MAP} / 1 \mathrm{~A}$ $(2.1 \mu \mathrm{g} / \mathrm{kg})$ among other locations.

The concentration of Benz (a)Pyrene in the sample media showed spatial distribution from one location to the other. Relatively high concentration of Benzo (a) Pyrene were found in MWM/9 (525.9 $\mu \mathrm{g} / \mathrm{kg}), \mathrm{RSD} / 20(514 . \mu \mathrm{g} / \mathrm{kg}), \mathrm{RA} / 18,(253.9 \mu \mathrm{g} / \mathrm{kg}), \mathrm{MAP} / 2(259.7$ $\mu \mathrm{g} / \mathrm{kg}$ ). The control samples recorded no detection (n.d) for CT and CT $/ 2(1.0 \mu \mathrm{g} / \mathrm{kg})$.

The concentration of Benzo (b) Fluoranthene showed varying concentration in the soils and sediments analysed. It was observed that the highest concentration of Benzo (b) Fluoranthene was found in location MMW/9 (502.6 $\mu \mathrm{g} / \mathrm{kg})$. Other locations with relatively high concentration include RSD/20 (452.9 $\mu \mathrm{g} / \mathrm{kg}), \mathrm{ID} / 4(280.2 \mu \mathrm{g} / \mathrm{kg})$ and RA/4 $(247.2 \mu \mathrm{g} / \mathrm{kg})$. When compared with the result of the control samples CT/4 (n.d), CT/2 $(2.8 \mu \mathrm{g} / \mathrm{kg})$ and other locations with relatively low concentration, such as FLG/3A $(1.1 \mu \mathrm{g} / \mathrm{kg})$ and SOC/2A $(8.7 \mu \mathrm{g} / \mathrm{kg})$. Moderate to low concentrations were recorded in most other locations

The result of the concentration of Benzo (ghi) Perylene in the soils and sediments also showed variation in the spatial distribution. The highest concentration was found in location MMW/16A $(557.8 \mu \mathrm{g} / \mathrm{kg})$, other locations with relatively high concentration of Benzo(ghi)Perylene include MMW/9 (500.9 $\mu \mathrm{g} / \mathrm{kg})$, MMW/18 (415.9 $\mu \mathrm{g} / \mathrm{kg})$, RSD $20(329.3 \mu \mathrm{g} / \mathrm{kg}) \mathrm{ID} / 9$ (326.6 $\mu \mathrm{g} / \mathrm{kg})$ among other locations when compared to the results of the control samples, CT/4 (n.d) and CT/2 (1.3) as well as some locations with relatively low concentration such as FLG/3A $(1.0 \mu \mathrm{g} / \mathrm{kg})$ and MAP/1A $(8.5 \mu \mathrm{g} / \mathrm{kg})$

Indeno (1,2,3-cd)pyrene compound showed spatial distribution from one location to the other. It was observed that the compound exhibited relatively high concentration in locations MMW/9 (412.2 $\mu \mathrm{g} / \mathrm{kg}), \mathrm{MMW} / 16 \mathrm{~A}(305.2 \mu \mathrm{g} / \mathrm{kg}), \mathrm{RSD} / 20(300.2 \mu \mathrm{g} / \mathrm{kg}) \mathrm{and} \mathrm{NK} / 14$ $(213.9 \mu \mathrm{g} / \mathrm{kg})$ compare to the results from the control samples CT/4 (n.d) and CT/2 (1.1 $\mu \mathrm{g} / \mathrm{kg})$. Other locations such as FLG/3A (1.0 $\mu \mathrm{g} / \mathrm{kg}), \mathrm{MAP} / 1 \mathrm{~A}(6.2 \mu \mathrm{g} / \mathrm{kg})$ and SOC$/ 2 \mathrm{~A}(5.2 \mu \mathrm{g} / \mathrm{kg})$ that recorded relatively low concentration.

The concentration of Dibenz(ah)anthracene generally showed relatively moderately low to low concentration in distribution. The highest concentration was found in location SSD/20 $(37.0 \mu \mathrm{g} / \mathrm{kg})$. Other locations with moderately low concentrations of the compound include MMW/9 $(33.4 \mu \mathrm{g} / \mathrm{kg}), \mathrm{RSD} / 14(18.1 \mu \mathrm{g} / \mathrm{kg}), \mathrm{ID} / 9(21.7 \mu \mathrm{g} / \mathrm{kg})$ and RA/4 $(22.8 \mu \mathrm{g} / \mathrm{kg})$, compare to the results of the control samples 
CT/4 (n.d) and CT/2 (n.d). Relatively low concentration were found in RA/21 (1.0 $\mu \mathrm{g} / \mathrm{kg}), \mathrm{SOC} / 5(1.0 \mu \mathrm{g} / \mathrm{kg})$ as well as many other locations.

The summary results for PAHs concentrations spatial distribution of soils and sediments analyzed are presented in figure 6 (a-k) It was observed that there is relative enrichment of PAHs in the soils and sediments studied. This is shown from the spatial distribution of the concentration from location to location, figure $6(\mathrm{a}-\mathrm{k})$ Generally across the samples collected and analyzed, there were high rate of detection of PAHs in the soils and sediments compare to the control samples which were collected from relatively pristine areas which are at the outskirt of the metropolis. Again the result showed higher concentration in mechanic and metal workshops (MMW) areas, Public parks, waste dump site than residential and farm land/garden soils. Also, high concentrations of PAHs were detected in sediments samples analysed from the side drains and the rivers of Ndemili and Nkisi. These suggest that soils and sediment within the city center and its runoff are more susceptible to the deposition of PAHs from anthropogenic sources such as vehicular emissions, use of herbicides, domestic waste degradation and waste polymer rich materials.

Table 1: Summary Results for PAHs Concentrations $(\mu \mathrm{g} / \mathrm{Kg})$ of Soils in Onitsha

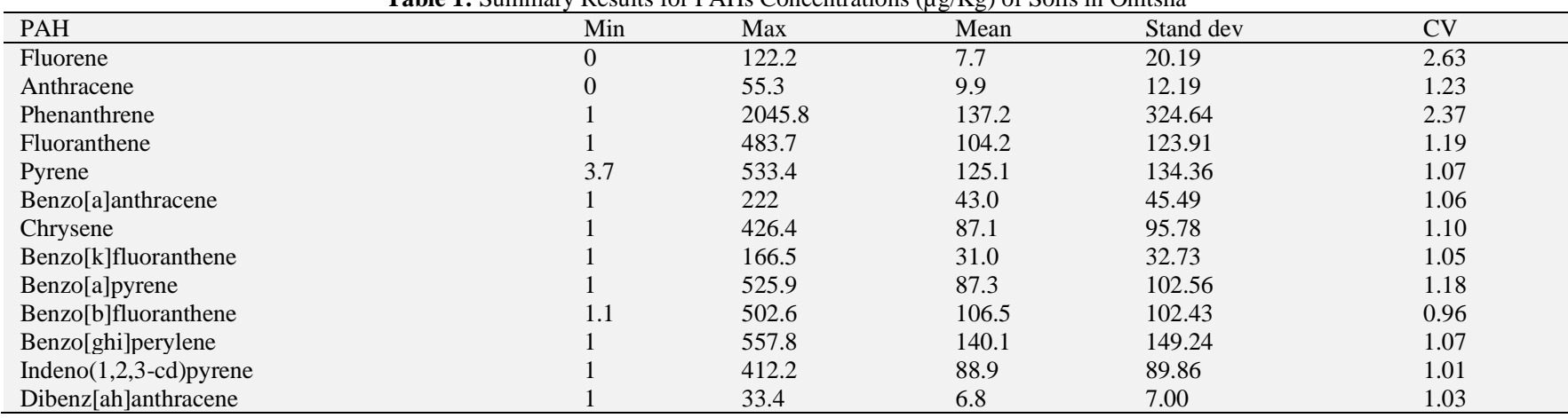

Table 2: Summary Results for PAHs Concentrations $(\mu \mathrm{g} / \mathrm{Kg}$ ) of Sediments in Onitsha

\begin{tabular}{|c|c|c|c|c|c|}
\hline $\mathrm{PAH}$ & Min & Max & Mean & Stand dev & $\mathrm{CV}$ \\
\hline Fluorene & 1.7 & 31.1 & 10.2 & 8.30 & 0.82 \\
\hline Anthracene & 1.7 & 46 & 19.8 & 12.81 & 0.65 \\
\hline Phenanthrene & 22.2 & 266.2 & 129.1 & 75.27 & 0.58 \\
\hline Fluoranthene & 13.4 & 602.9 & 187.2 & 146.43 & 0.78 \\
\hline Pyrene & 14.1 & 531.8 & 187.5 & 133.67 & 0.71 \\
\hline Benzo[a]anthracene & 5.6 & 298.3 & 93.8 & 71.96 & 0.77 \\
\hline Chrysene & 10 & 385.6 & 150.4 & 94.81 & 0.63 \\
\hline Benzo[k]fluoranthene & 4 & 163.5 & 64.5 & 35.10 & 0.54 \\
\hline Benzo[b]fluoranthene & 14.1 & 452.9 & 200.6 & 109.12 & 0.54 \\
\hline Benzo[ghi]perylene & 25.5 & 449.8 & 209.9 & 104.48 & 0.50 \\
\hline Indeno(1,2,3-cd)pyrene & 14.9 & 326 & 169.0 & 81.49 & 0.48 \\
\hline Dibenz[ah]anthracene & 1 & 37 & 13.2 & 8.11 & 0.62 \\
\hline
\end{tabular}
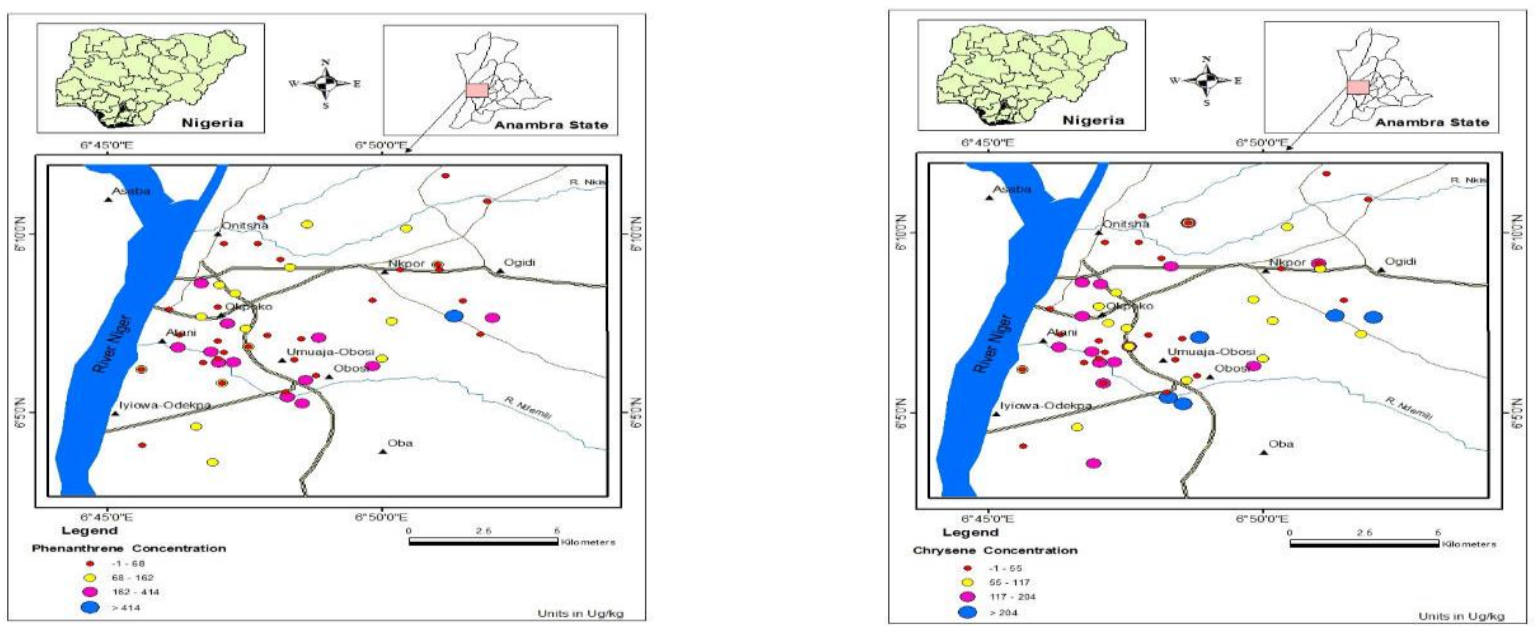

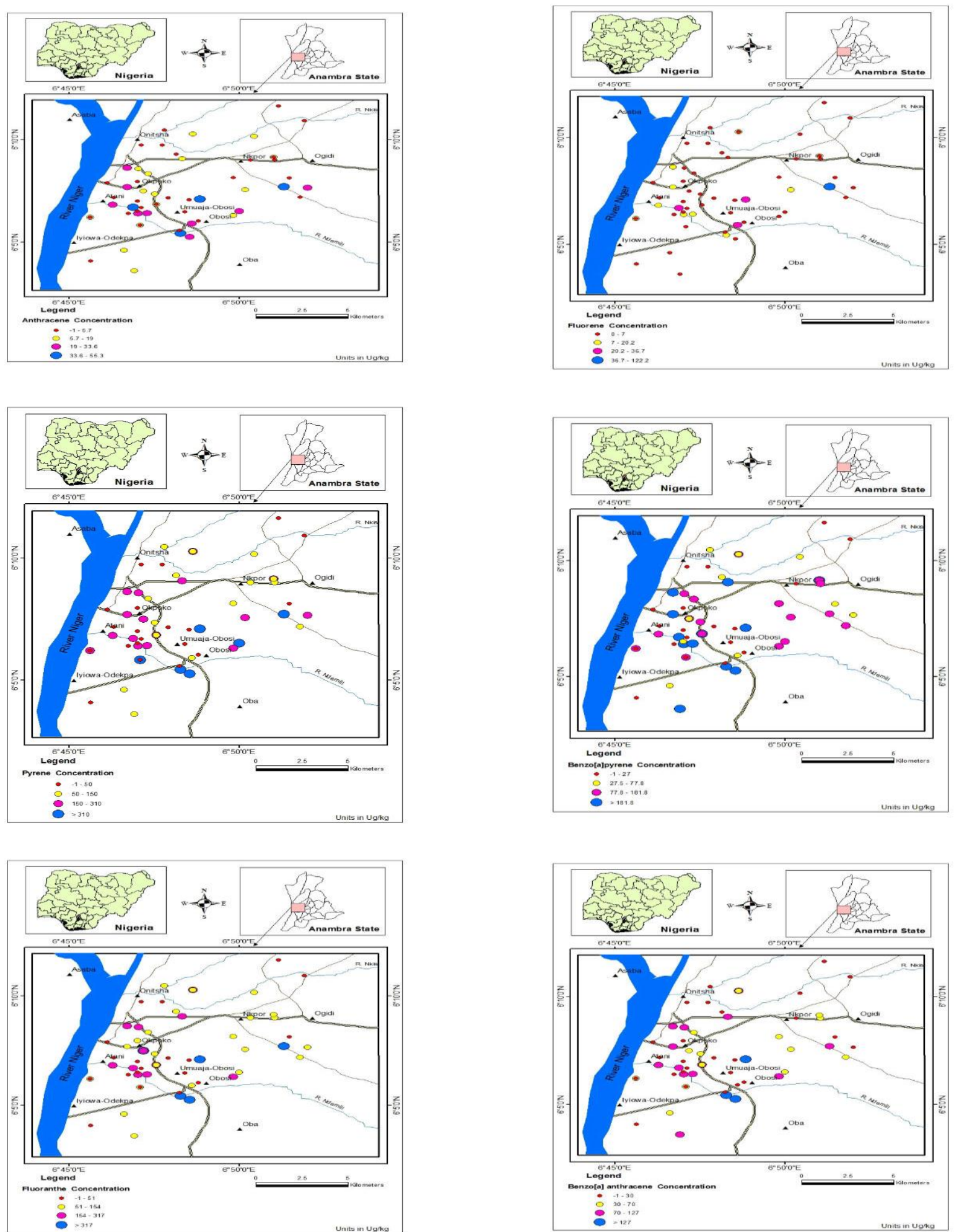

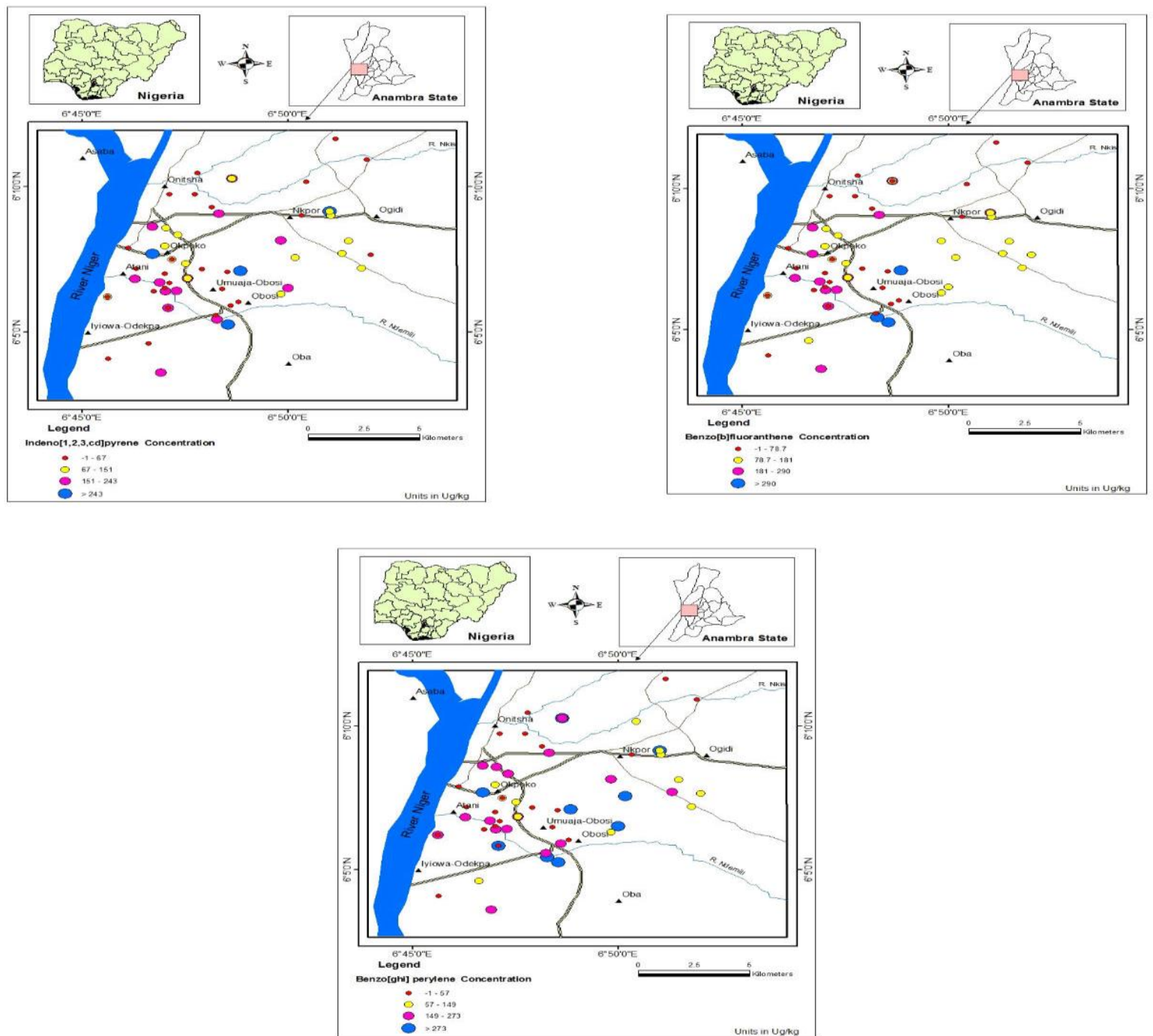

Fig. 6: $(a-k)$ Spatial Distribution of PAHs Concentration in Soils and Sediments of the Area.

The relatively high presence of High Molecular Weight PAHs (HMW) as against the Low Molecular Weight (LMW) PAHs in the soils and sediments as observed suggests that the PAHs are as a result of pyrogenic processes as the dominant sources of PAHs. The HMW PAHs include; Fluoranthrene, Pyrene, Benzo[a]anthracene, Crysene, Benzo[b]fluoranthene, Benzo[ghi]perylene, Indeno(1,2,3-cd)pyrene and Dibenzo[ah]anthracene. While the LMW PAHs include Fluorene, Anthracene and Phenanthrene, Table1 and Table 2. It has been reported in many published works (Morillo et al., 2007; Wilcke, 2007 and Glennon et al. 2012) that pyrogenic contamination is characterized by high presence of HWM PAHs over LWMPAHs in soils and sediments.

Though scientific data on PAHs characteristics in urban areas are few, the soils and sediments that were investigated in this study was compared with results of published works from other countries, especially with respect to those countries that are relatively large with high industrial activities. It was observed that the soils and sediment analyzed are relatively high (Table 4.20). the 16 PAHs that were analyzed in the city of Beijing, China showed $(467-5470 \mu \mathrm{g} / \mathrm{kg})$ of surface soils, while Valasske Mezirici, Czech Republic showed (861-3514 $\mu \mathrm{g} / \mathrm{kg}$ ) among others in Table 4.20, as compared with our findings (20.0-4281.4 $\mu \mathrm{g} / \mathrm{kg})$ for 13 PAHs, this showed that the soils and sediments in the study area is of great concern, because there is considerably enrichment in the soils and sediment to pollution status.

There was relatively non correlation relationship between the TOC and total PAH concentrations, figure (7a) which apparently suggest that the PAH in the soil are recent contamination and as established by different authors such as (Olatunbusun et al., 2011) yet to fully be partitioned into the organic matter in the soils. Olatunbusun et al. 2011, Baumard et al., 1999 and Simpson et al., 1996 have showed that relationship between TOC and total PAHs in the sediment was significant only if the area is highly contaminated to PAHs of $>2000$ $\mu \mathrm{g} / \mathrm{kg} \mathrm{dw}$. This is further buttressed by the three component principal plot for the compounds with the TOC, figure (7b), which shows clearly that the PAH occur almost together in cluster form suggesting similar sources of enrichment in the soil and sediment as against the TOC that exhibit non similar occurrence.

Table 3: Comparative Distribution of Polycyclic Aromatic Hydrocarbon of Selected Countries I the World and the Results of This Study

\begin{tabular}{lllll}
\hline Location & No of PAHs & $\sum$ PAHs $(\mu \mathrm{g} / \mathrm{kg})$ & Source type & Reference \\
\hline Korea Peninsula & 13 & $109-178$ & Industrial & (Hashmi et al. 2005) \\
Beijing, China & 16 & $467-5470$ & Urban soil & (Li et al. 2006) \\
Beijing, China & 16 & $16-3884$ & Surface soil & (Ma et al. 2005) \\
Canada & 17 & 1400 & Highway & (Wang and Meresz 1982 \\
United Kingdom & 7 & 2000 & Motorway & (Butler et al. 1984) \\
United Kingdom & 16 & 187 & Rural soils & (Wild and Jones 1995) \\
United States & 14 & 3000 & Highway & (Yang et al. 1991) \\
Japan & 8 & 1300800 & Urban soil & (Spitzer and Kuwatsuka 1993) \\
\hline
\end{tabular}




\begin{tabular}{|c|c|c|c|c|}
\hline United Kingdom & 16 & 2700500 & Urban soil & (Meharg et al. 1998) \\
\hline New Orleans, United States & 16 & $3731 \mathrm{a}$ & Urban soil & (Mielke et al. 2001) \\
\hline West Macedonia, Greece & 16 & $55.2-495$ & Lignite fire & (Stalikas, Chaidou, and Pilidis 1997) \\
\hline Igbanko mangrove forest Lagos & 16 & $65.5-188.0$ & Forest fire soil & Olatunbosun et al. 2011 \\
\hline Valasske Mezirici, Czech Rep. & 16 & $861-3514$ & Agric/urban soils & Daniela et al. 2009 \\
\hline Onitsha & 13 & $20.0-4281.4$ & soils and sediments & Current study \\
\hline
\end{tabular}

(A)

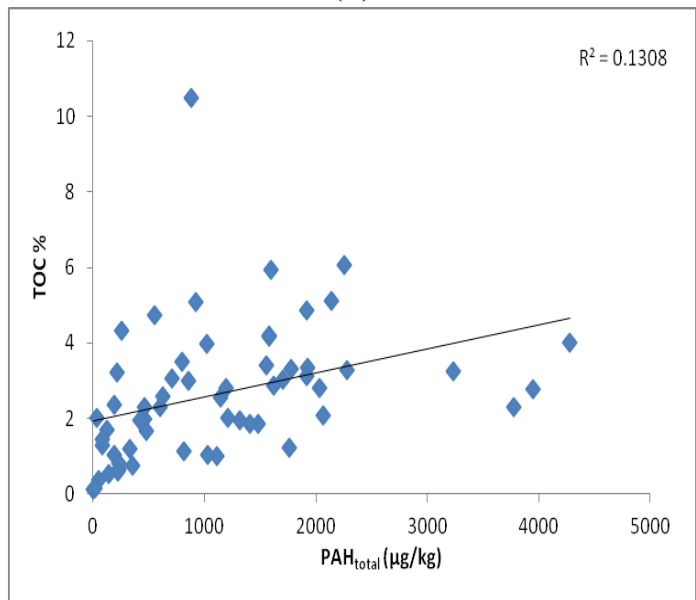

(B)

Component Plot

Fig. 7: (A-B) Bivariate and PCA Plot of Between Total Pahs and TOC (\%) for Soils and Sediments in the Study Area.

\subsection{Identification of sources of PAHs in soils and sediment of the study area}

The potential sources of PAH in the soils and sediments were carried out using PAH isomer ratio in other to identify the possible sources of these harmful compound. This is a method that have been used by published works, such as (Baumard et al.; 1998, Ma et al. 2005, Liu et al. 2008and Glennon et al., 2012) to ascertain weather it is from pyrolytic i.e (Combustion) processes of organic rich matereials or through petrogenic input i.e (through petroleum product discharch like oil spillage). When the ratio of Flu/(Flu + Pry) is $<0.4$, it suggest petroleum source enrichment while Flu/(Flu $+\mathrm{Pyr})$ is $>0.5$ it indicates PAH in the geo media is from combustion of grass, wood and coal and when $(\mathrm{Flu} /(\mathrm{Flu}+\mathrm{pyr})$ is between $0.4<$ and $>0.5$, it is from combustion of petroleum product ( $\mathrm{Li}$ et al. 2006)

In similar vain, the ratio of Ant/(Ant $+\mathrm{Pyr})<0.1$ are such enriched by petroleum product contamination, while the ratio of Ant/(Ant + Pyr) ratio $>0.1$ are mainly from combustion related sources such as vehicle related activities (Li et al 2006). The ratio of IcdP/(Icdp + $\mathrm{BiP})<0.2$, shows petroleum sources while value $>0.5$, indicate pyrolytic sources (Yunker et al, 2002). The same apply to the ratio of $\mathrm{BaA} /(\mathrm{BaA}+\mathrm{Chr})$. When $\mathrm{BaA} /(\mathrm{BaA}+\mathrm{Chr})$ ratio is $<0.2$, it indicate petroleum input while when it is $>0.35$, it indicate pyrolytic sources (Yinker et al. 2002). From the result of this work, it is observed that for the ratio of Flu/Flu + Pry), is between $<0.4$ and $>0.5$ for most of the locations which suggest petroleum combustion, grass, wood and coal combustion sources enrichment for most of the locations while there are some few samples which indicate petroleum product waste, figure 8., in the ratio reading. The locations that recorded $>0.6$ suggest combustion of organic rich waste matrerials as in location AWD/5B which is soil sample collected within the vicinity of active waste dump site.

Similarly, the ratio of $\mathrm{BaA} /(\mathrm{BaA}+\mathrm{Chr})$ in this study shown that most of the samples plotted within the vicinity of pyrogenic sources of PAHs enrichment in both soils and sediments. Though some of the samples collected analysed ratios also indicated petrogenic sources of PAHs enrichment in both soils and sediments, figure 9.

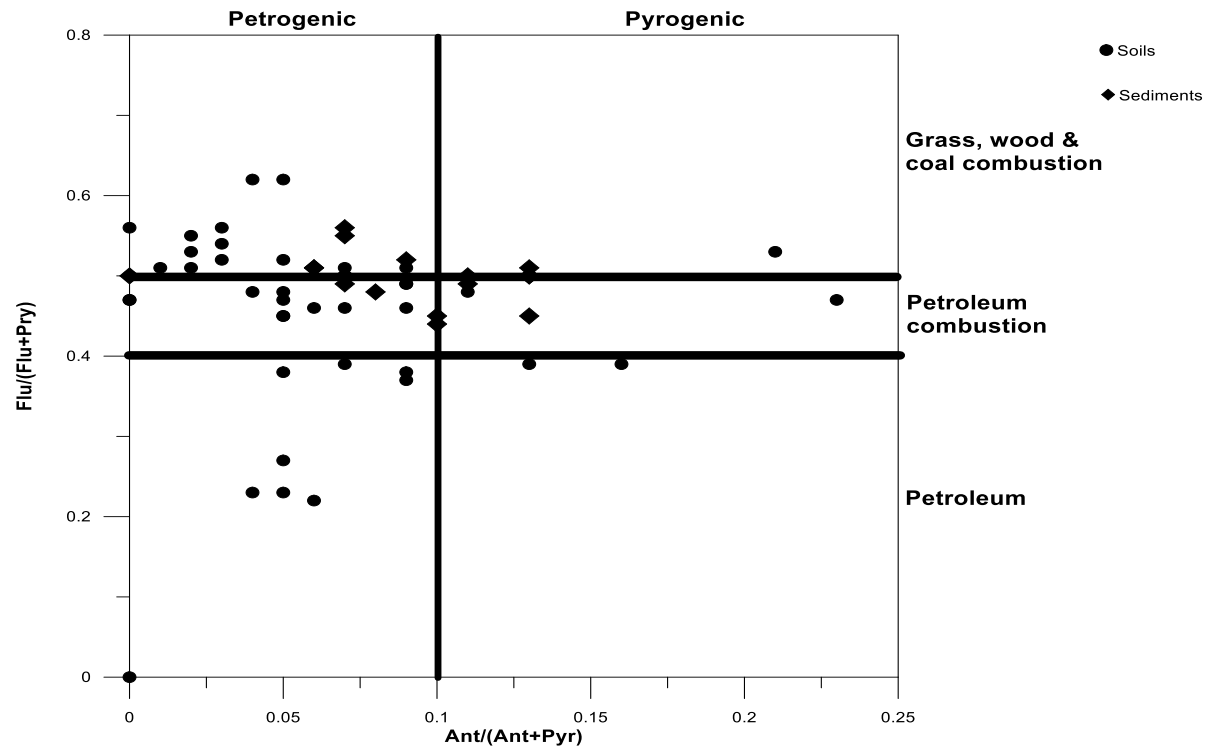

Fig. 8: A Plot of Anthracene/(Anthracene + Phenanthrene) Versus Fluoranthene/( Fluoranthene + Pyrene) in Soils and Sediments of Onitsha Area. 


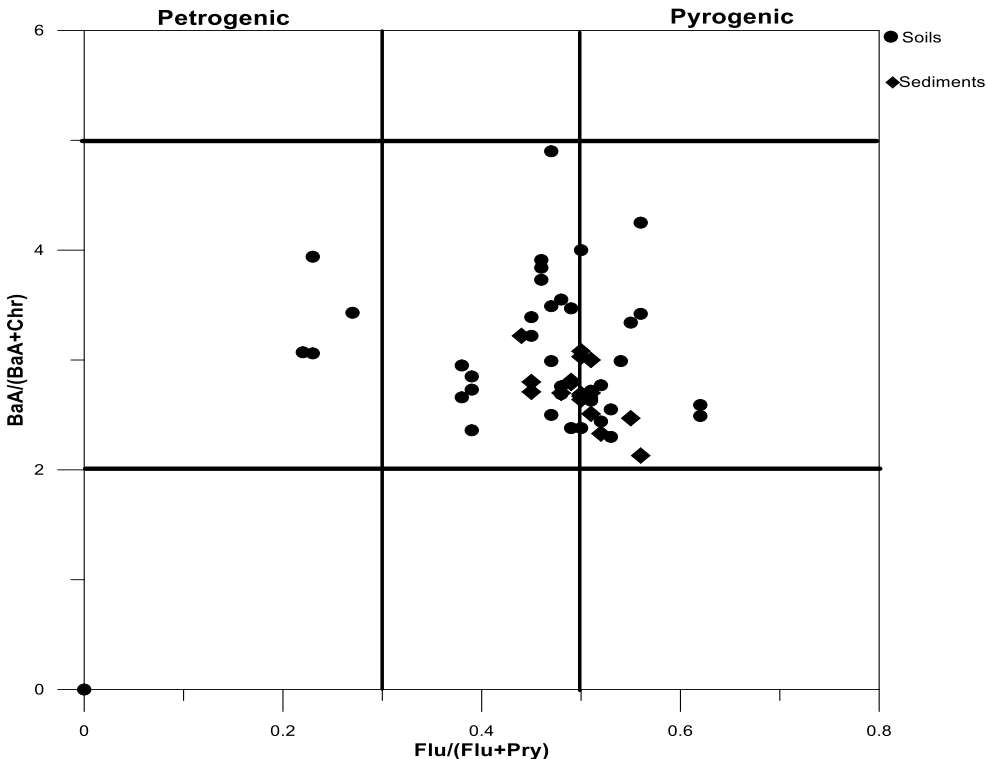

Fig. 9: A Plot of Benzo[A]Anthracene /( Benzo[A]Anthracene + Chrysene ) Versus Fluoranthene/( Fluoranthene + Pyrene) in Soils and Sediments of Onitsha Area.

\section{Conclusions}

The result of spatial distribution of PAHs in the soils and sediments showed relatively high content of 13 PAHs of the 16PAHs that are of environmental concern. These PAHs include Fluorene, Anthracene, Phenanthrene, Fluoranthrene, Pyrene, Benzo[a]anthracene, Crysene, Benzo[b]fluoranthene, Benzo[ghi]perylene, Indeno(1,2,3-cd)pyrene and Dibenzo[ah]anthracene. The other three PAHs that were not detected include Naphthalene, Acenaphthylene and Acenaphthene. From the results, varying concentration of these PAHs were found from one location to the other for both soils and sediments. It was observed that land use activities was a major factor that influence the varying concentration of these organic compound, were areas such as MWM/11 (127.8 $\mu \mathrm{g} / \mathrm{kg}), \mathrm{RSD} / 20(298.3 \mu \mathrm{g} / \mathrm{kg})$, ID/9 (226.6 $\mu \mathrm{g} / \mathrm{kg}$ ), of Benzo (a) anthracene compound that were found to be relatively high compare to their content in the control samples which Is below the detection limit of the analytical facility employed in their analysis

Similarly the varying concentrations other PAHs that suggest influence of high urban activities, for example, Benzo[k] Fluoranthene compound, MMW/9 (166.5 $\mu \mathrm{g} / \mathrm{kg}), \mathrm{SSD} / 20(163.5 \mu \mathrm{g} / \mathrm{kg}), \mathrm{ID} / 9(106.6 \mu \mathrm{g} / \mathrm{kg})$, and MAP/2 $(84.9 \mu \mathrm{g} / \mathrm{kg})$ compare to the result from the control samples, such as CT/4 (n.d), CT/2 $(1.0 \mu \mathrm{g} / \mathrm{kg})$. such pattern of PAHs enrichment in soils and sediment were found in Benz(a)Pyrene, Benzo(b) Fluoranthene, Benzo(ghi)Perylene, Indeno (1,2,3-cd)pyrene among other PAHs detected. The identification characterization of the possible sources of PAHs that were interpreted showed that most of the PAHs found in the soils and sediments of the study are related to pyrogenic sources which may have been influenced by combustion related activities within the urban environment. The main concern about PAHs presence to such level of concentration in some vital locations within the soils and sediments analysed is the fact that the PAHs detected are carcinogenic and mutagenic when it comes in contact with human beings most especially through pathways such as dust inhalation, surface water intake by plants and animals that depend on such, among other possible pathways.

\section{References}

[1] Appleton, J. D., Fuge, R. and McCall, G. J. H. 1996. Environmental Geochemistry and Health with Special Reference to Developing Countries. Geological Sociely Special Publication No. 113, 264p.

[2] Baumard, P., H. Budzinski, P. Garrigues, H. Dizer, and P.D. Hansen. 1999. Polycyclic aromatic hydrocarbons in recent sediments and mussels (Mytilus edulis) from the western Baltic sea:Occurrence, bioavailability and seasonal variations. Marine Environmental Research 47: 17-47. https://doi.org/10.1016/S0141-1136(98)00105-6.

[3] Baumard, P., H. Budzinski, P. Garrigues, J.C. Sorbe, T. Burgeot, and J. Bellocq. 1998. Concentration of PAHs (polycyclic aromatic hydrocarbons) in various marine organisms inrelation to those in sediments and to trophic level. Marine Pollution Bulletin 36: 951-60. https://doi.org/10.1016/S0025-326X(98)00088-5.

[4] Butler, J.D. Butterworth, V. Kellow, S.C. and Robinson, H.G. (1984) some observations on the polycyclic aromatic hydrocarbon (PAH) content of surface soils in urban areas, Sci. Total Environ. 33 75-85. https://doi.org/10.1016/0048-9697(84)90382-6.

[5] Chung, M.K., Hu, R., Cheung, K.C., Wong, M.H., 2007. Pollutants in Hong Kong soils:polycyclic aromatic hydrocarbons. Chemosphere 67, 464473. https://doi.org/10.1016/j.chemosphere.2006.09.062.

[6] Daniela Plachá, Helena Raclavská, Dalibor Matýsek and Mark H Rümmeli, 2009. The polycyclic aromatic hydrocarbon concentrations in soils in theRegion of Valasske Mezirici, the Czech Republic, Geochemical Transactions 2009, 10:12 https://doi.org/10.1186/1467-4866-10-12.

[7] Federal Survey Nigeria, Sheet 263, map publication 1964.

[8] Hafner, W.D., Carlson, D.L., Hites, R.A., 2005. Influence of local human population on atmospheric polycyclic aromatic hydrocarbon concentrations. Environ. Sci. Technol. 39, 7374-7379. https://doi.org/10.1021/es0508673.

[9] Hashmi, I., G.K. Jong, S.K. Kyoung, and P. JI-Soo. 2005. Polyaromatic hydrocarbons (PAHs) levels from two industrial zones (Sihwa and Banwal) located in An-san city of the KoreanPeninsula and their influence on lake. Journal of Applied Sciences and Environmental Management9: 639. https://doi.org/10.4314/jasem.v9i3.17354.

[10] Johnsen, A.R., De Lipthay, J.R., Reichenberg, F., Sorensen, S.J., Andersen, O., Christensen, P., Binderup, M.-L., Jacobsen, C.S., 2006. Biodegradation, bioaccessibility, and genotoxicity of diffuse polycyclic aromatic hydrocarbon (PAH) pollution at a Motorway Site. Environ. Sci. Technol. 40, 3293-3298. https://doi.org/10.1021/es060008u.

[11] Li, X., Ma L., Liu X., Fu S., Cheng H., and Xu X. 2006. Polycyclic aromatic hydrocarbon in urban soil from Beijing, China. Journal of Environmental Sciences 18: 944-50. https://doi.org/10.1016/S1001-0742(06)60019-3. 
[12] Liu, Y., L. Chen, Z. Jianfu, Q. Huang, Z. Zhiliang, and G. Hongwen. 2008. Distribution and sources of polycyclic aromatic hydrocarbons in surface sediments of rivers and an estuary in Shanghai, China. Environmental Pollution 154: 298-305. https://doi.org/10.1016/j.envpol.2007.10.020.

[13] Ma, L.L., S.G. Chu, X.T. Wang, H.X. Cheng, X.F. Liu, and X.B. Xu. 2005. Polycyclic aromatic hydrocarbons in the surface soils from outskirts of Beijing, China. Chemosphere 58: 1355-63. https://doi.org/10.1016/j.chemosphere.2004.09.083.

[14] Meharg, A.A., J. Wright, H. Dyke, and D. Osborn. 1998. Polycyclic aromatic hydrocarbon (PAHs) dispersion and deposition to vegetation and soil following a large scale chemical fire.Environmental Pollution 99: 29-36. https://doi.org/10.1016/S0269-7491(97)00180-2.

[15] Mielke, H.W., G. Wang, C.R. Gonzales, B. Le, V.N. Quach, and P.W. Mielke. 2001. PAHs and metal mixtures in New Orleans soils and sediments. Science of the Total Environment 281:217-27. https://doi.org/10.1016/S0048-9697(01)00848-8.

[16] National Population Commission. 2007. Federal Republic of Nigeria official Gazette of the details of Breakdown of the National and State provisional totals 2006 Census. Printed and published by FG printer, Lagos. No 24, vol 94, B175 - 198.

[17] Nwajide, C.S., (2013). Geology of Nigeria's Sedimentary Basins, A CSS Bookshops Limited Lagos, Nigeria, 565p.

[18] Olatunbosun S. Sojinuab, Oluwadayo O. Sonibare C and Eddy Y. Z; 2011.Toxicological \& Environmental Chemistry. Vol. 93, No. 3, March, 450461Concentrations of polycyclic aromatic hydrocarbons in soils of a mangrove forest affected by forest fire. https://doi.org/10.1080/02772248.2010.532130.

[19] Pies C, Hoffmann B, Petrowsky J, Yang Y, Ternes TA, Hofmann T: 2008. Characterization and source identification of polycyclic aromatic hydrocarbons (PAHs) in river bank soils. Chemosphere, 72:1594-160. https://doi.org/10.1016/j.chemosphere.2008.04.021.

[20] Simpson, C.D., Mosi, A.A., Cullen, W.R., Reimer, K.J., 1996. Composition and distribution of polycyclic aromatic hydrocarbon contamination in surficial marine sediments from Kitimat Harbor, Canada. Sci. Total Environ. 181, 265-278. https://doi.org/10.1016/0048-9697(95)05026-4.

[21] Spitzer, T., and S. Kuwatsuka. 1993. Residue levels of polynuclear aromatic compounds in urbansurface soil from Japan. Journal Chromatography 643: 305-9. https://doi.org/10.1016/0021-9673(93)80563-N.

[22] Stalikas, C.D. Chaidou, C.I. Pilidis, G. A. (1997). Enrichment of PAHs and heavy metals in soils in the vicinity of the lignite-fired power plants of West Macedonia, Sci. Total Environ. 204 135-146. https://doi.org/10.1016/S0048-9697(97)00156-3.

[23] Torben Nielsen, Hans E. Jsrgensen, John Chr. Larsenb and Morten Poulsenb, 1996. City air pollution of polycyclic aromatic hydrocarbons and other mutagens: occurrence, sources and health effects. The Science of the Total Environment 189/190: 41-49. https://doi.org/10.1016/00489697(96)05189-3.

[24] Trapido, M. 1999. Polycyclic aromatic hydrocarbons in Estonian soil: contamination and pro®les. Environmental Pollution 105: 67-74. https://doi.org/10.1016/S0269-7491(98)00207-3.

[25] U.S. Environmental Protection Agency (USEPA). 2002 USEPA Guidelines for sediments http/www.epa.gov.

[26] Vila-Escale, M., Vegas-Vilarrubia, T., Prat, N., 2007. Release of polycyclic aromatic compounds into a Mediterranean creek (Catalonia, NE Spain) after a forest fire. Water Res. 41, 2171-2179. https://doi.org/10.1016/j.watres.2006.07.029.

[27] Wang, D.T., and O. Meresz. 1982. Occurence and potential uptake of polynucleararomatic hydrocarbons of highway traffic origin by proximally grown food crops.

[28] 460 O.S. Sojinu et al. 011In Polynuclear aromatic hydrocarbons: Physical and biological chemistry, ed. M. Cooke, A.J. Dennis, and G.L. Fischer, 885-96. New York: Springer-Verlag.

[29] Wendi Zheng Joseph Lichwa and Tao Yan, 2011. Impact of different land uses on polycyclic aromatic hydrocarbon contamination in coastal stream sediments. Chemosphere 84: 376-382. https://doi.org/10.1016/j.chemosphere.2011.03.067.

[30] Wild, S.R. and Jones,K.C. (1995) Polynuclear aromatic hydrocarbons in the United Kingdomenvironment: a preliminary source inventory and budget, Environ. Pollut. 88: 91-108. https://doi.org/10.1016/0269-7491(95)91052-M.

[31] Yang, S.Y.N., Connell, D.W. Hawker, D.W. Kayal, S.I. (1991). Polycyclic aromatic hydrocarbons in air, soil and vegetation in the vicinity of an urban roadway, Sci. TotalEnviron. 102. https://doi.org/10.1016/0048-9697(91)90317-8.

[32] Yunker, M.B., Macdonald, R.W., Vingarzan, R., Mitchell, R.H., Goyette, D., Sylvestre, S., 2002. PAHs in the Fraser River basin: a critical appraisal of PAH ratios as indicators of PAH source and composition. Org. Geochem. 33, 489-515. https://doi.org/10.1016/S0146-6380(02)00002-5.

[33] Zheng W, Lichwa J, Yan T, 2011. Impact of different land uses on polycyclic aromatic hydrocarbon contamination in coastal stream sediments. Chemosphere 84, 376 - 384 https://doi.org/10.1016/j.chemosphere.2011.03.067. 